\title{
回転機マイカ・レジン絶縁コイルの絶縁 劣化診断方法の一考察
}

\author{
正員 門 谷 建 蔵 (日立)
}

\section{1. まえがき}

電力機器の大容量化高機能化に伴い，事故が発生し た場合の社会的影響と経済的損失の規模がますます 大きくなること加ら，予防保全技術が重視されつつあ る。回転機絶縁においても，定期点梌時の非破㙹測定 を通じて巻線の絶縁劣化度をはあくする，絶縁劣化診 断技術の重要性が認識されている。

アスファルトコンパウンド絶縁の発電機巻線につい ては，有用な絶縁劣化判定基準が定められている(1)。 しかし，現在運転中の発電機および電動機は，含浸レ ジンに合成樹脂)例えぱ，不飽和ポリエステル，エポキ シ)在用いた、いわゆるレジン絶縁巻線になっている。 レジン絶縁巻線についての絶縁劣化判定基準はまだ定 まっておらず，一般的にはさきの判定基準を流用して いる(2)。コンパウンド絶縁からレジン絶縁化代わり， レジン絶縁の優れた耐熱性，耐機械力および絶縁酎力 を生かして、より過酷な設計をするようになったた め，絶縁層の劣化の仕方が巽なってきている。例え ば，熱劣化の影㗽は軽隇され，相対的に機械的応力に よる劣化の影響が大きくなっている。このよう仿劣化 形態が異なると，当然劣化判定の基染屯罢なるべきで ある。

さきの判定基华に抬りる試験項目はそのままで，合 否判定の基準値だ村を変えてやればよいのか。コンパ ウンド絶縁の劣化判定には有用であった交流電流試験 や直流試験が，レジン絶縁には適用できないとの報告 功多く見られ ${ }^{(3)}$ ，レジン絶縁の秀化判定は非常に困嚾 視されてきている。部分放電特性の詳細な解析 ${ }^{(4)}$ ， あ るいは交流電流特性を非常な高感度でとらえる「自動

A Study on the Insulation Diagnostic Methods for Mica.Resin Insulated Coils of Rotating Machines. By Kenzo Kadotani, Member (Hitachi Research Laboratory, Hitachi Ltd.).

阴谷建蔵：正員，(嫩)日立筡作所日立研究所
絶縁特性解析装置 (AIA)」の開発がなされ( ${ }^{(5)}$, 診断の ための情報は多く得られるようになったが，それらの 情報办ら巻線の残存䋓縁破壊電圧を推定する手法化つ いては，まだデータの蓄樍段階にある。

筆者らも，コイルの平部に独立した分割電極を設け ること，あるいはかなりの高電压を印加して AIA で 測定することによって，残存絶縁破壞電圧上相関性の ある非破壊測定值が得られることを見いだしたが(6)， いずれの方法む運転中の回転機巻線に適用するのは困 難と思われる。次いでエポキシ絶縁のモデルコイルに

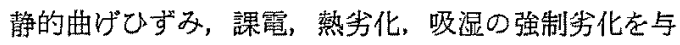
元て実験し，残存絶绿破堎電圧を非破壊測定值 $\tan 80$ (低電圧, 普通 $2 \mathrm{kV}$ で測定した絶縁層の誘電正接)上 $\Delta \tan \delta+\Delta C / C_{0}$ (第 1 表参照) 加算出するための寒 噃式老出した ${ }^{(7)}$ 。

本諭文は運転中の回転機レジン絶縁巻線の残存絶縁 酎力を推定する手法について，経年運転少化を受けた 巻線コイルの検討結果に，強制劣化を与えたモデルコ イルの検㲅結果を組合せて解析するととにより，基整 的铪討を行なったすのである。

\section{2. 䋓縁診断の手法}

〈2・1〉 絶縁層の劣化形態回転機高圧巻線の絶 縁層は，主としてマイカとレジンからなる。運転中の 各種複合ストレスによって絶縁層に発生する少化の形 態には，第1図にモデル的に示した以下のむのが考 えられる。(1)ジンの変質 (熱分解)，(2レジンの炭 化，(3)レジンの吸湿，(4)レジンの分解によって生じた 空孔, (5)マイカ・レジン界面の微小はくり，(6)大面積 のはくり(酋はがれ)，(7)絶縁基材を貫通するクラック

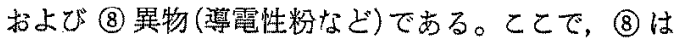
(6)や(7)を生じる原因となる可能性がある潜在的欠陒 であるが，以下では考察しない。 


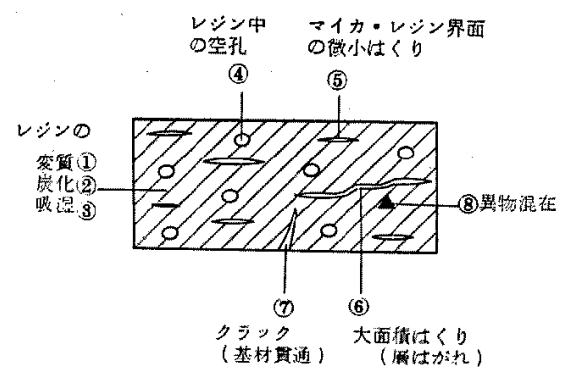

第 1 図 マイカ・レジン絶縁層のモデル

Fig. 1. A model of mica-resin insulation.

(1)〜3は固体絶縁物自体の変化であり，劣化䎲よっ て可とう性が低下しあるいはマイカとの接着性が弱ま り，他の(4)〜(7)の少化を起こりやすくする。(4)捛よび (5はレジン中の空孔执よびマイカ・レジン界面の微小 はくりであり，課電によって部分放電を生じて周囲の 絶縁物を劣化させ，また機械的応力に上り，(6)，(7) 移行する恐れがある。(1)〜(5)の劣化は，それをあらか じめ考慮して絶縁厚さを決めているので，「定常劣化」 と称してむよい。6 (6)（7)の劣化む，現在のとてろでは 考虑してそれなりに絶縁厚さを十分にとっているが， それらの分化が全く起てらなければ更に薄くできると いう意味では，一応「異常劣化」と称してもよい。こと では(1)〜(5)が絶縁層のいたるところに生じる一様少化 であるのに対して，局所劣化と称してよいと考える。 局所劣化は非常に絶縁耐力の弱い通路在長い距離に及 び生じさせることになり，絶縁層の絶縁耐力を著しく 低下させる。

$\langle 2 \cdot 2\rangle$ 非破壊測定值の種類 ，絶縁層の劣化形態 は上述のように2 種に分けられる。一方で絶縁診断の ための非破填試駼沈りる湘定値は多数ある。第 1 表 はそれらの測定值の符号と一般的な定義，および上述 の 2 種の劣化を猃断する場合の相関性をまとめた。な お，一様劣化は先述の (1)〜(3)および (4)，(5)の 2 群に分 けた。第 1 表から次のことが言える。

(i) 絶縁物の少化 (1) (3)) は，低電圧の交流で測 定した值 $\left(\tan \delta \delta_{0} ， C_{0}\right)$ 括よび直流で測定した値 $(R, P I)$ と相関がある。

（ii）一稼劣化に属するボイドや微小なはくりは， 交流の低電圧を加えたときと高電圧を加えたときで， 部分放電が生じることによって変化する值 $(\Delta \tan \delta$, $\left.\Delta C / C_{0}, V_{i}, P_{i 1}, P_{i 2}, \Delta I, m, \gamma, Q_{m}, \Sigma Q N\right)$ 之相関があ る。

（屰）局所劣化は，その籄所の部分放電発生電圧を AIA に上る测定值 $m$ や $\gamma^{(5)}$ 加ら精度良くとらえる か，最大放電電荷 $Q_{m}$ を測定すれば，その大きさ拈よ
第 1 表 䋓縁診断のための测定值

Table 1. Measures for insutation diagnosis.

\begin{tabular}{|c|c|c|c|c|}
\hline \multirow{2}{*}{ 一幋的 } & \multirow[b]{2}{*}{ 一般的な定韽 } & \multicolumn{3}{|c|}{ 䛦欮内容および相関比 } \\
\hline & & 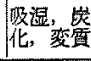 & $\begin{array}{l}\text { はくり } \\
\text { ボイト }\end{array}$ & 㡟所異 \\
\hline $\tan \delta_{0}$ & 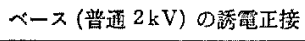 & 0 & & \\
\hline$C_{8}$ & 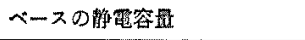 & 0 & & \\
\hline$R$ & 絹 粶 抵 抗 & $\mathrm{O}$ & & \\
\hline$P I$ & 成 極 指 数 & $\mathrm{O}$ & & \\
\hline$\Delta \tan \delta$ & 定格露王 $(E) \circlearrowleft \tan \delta_{E}-\tan \delta_{0}$ & & 0 & \\
\hline$\Delta C / C_{0}$ & 静電容艋增加藩， $\left(C_{E}-C_{0}\right) / C_{0}$ & & 0 & \\
\hline$V_{i}$ & 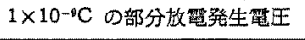 & & $\Delta$ & $\Delta$ \\
\hline$P_{i,}, P_{i z}$ & 交流電流試験の電流急增点 & & 0 & \\
\hline$\Delta I$ & 䇴流增加乘， $=\Delta C / C_{0}$ & & 0 & \\
\hline$m, \gamma$ & AIA による测定值 ${ }^{(5)}$ & & 0 & $\Delta \sim 0$ \\
\hline$Q_{m}$ & 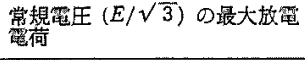 & . & $\triangle$ & 0 \\
\hline$\Sigma Q N$ & 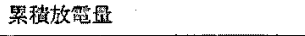 & & 0 & $\Delta$ \\
\hline
\end{tabular}

○：かなり良い、・：ある，空白はほとんどない。

び形状に関する情報が得られるであるう。

上記の（i ）（而）項にこれぞれ区分けされた測定値 の間では，それぞれ良い相関性のあることが，実験 と 理論の両面から確かめられている(3)。

$\langle 2 \cdot 3\rangle$ 残存絶縁破壊電圧の推定手法 $\langle 2 \cdot 1\rangle$ 節の 3 種の劣化形態を $X$ (1) (3)， $Y$ (4), (5),$Z$ ((6), (7) とする之，劣化したコイルの残存絶緑破壊電圧 $V_{R}$ (末 少化コイルを $100 \%$ 上する％表示をする)を，それぞ れの劣化形態がそれぞれ独立に作用すると仮定して，

最す単純な式で表わすと次式のようになる。

$$
V_{R}=100-F_{1}(X)-F_{2}(Y)-F_{3}(Z) \ldots(1)
$$

ここで，例えば $F_{1}(X)$ は劣化形態 $X$ による破壊 電圧の低下を表わす関数である。

劣化形態 $X, Y, Z$ とそれぞれ相関のある非破壊測 定值 $x, y, z$ 老用いると，次式のようにして $V_{R}$ を $x, y, z$ から算出できるようになる。

$$
V_{R}=100-f_{1}(x)-f_{2}(y)-f_{3}(z) \ldots \ldots .
$$

$x, y, z$ として，第 1 表加ら $\tan \delta 0, \Delta(=\Delta \tan \delta+$ $\left.\Delta C / C_{0}\right) ， Q_{m}$ を選び, 最も簡単な(3)式で表わすこと の可能性老考察する。ここで「」は初期未劣化コイル の值を表わし， $k_{1}, k_{2}, k_{3}$ は絶縁組織によって固有の 定数である。

$$
\begin{aligned}
V_{R}= & 100-k_{1}\left(\tan \delta_{0}-\tan \delta_{0}^{\prime}\right) \\
& -k_{2}\left(\Delta-\Delta^{\prime}\right)-k_{3} \log \left(Q_{m} / Q_{m^{\prime}}\right)
\end{aligned}
$$

通常の乾燥しているコイルでは， $\tan \delta_{0}$ の変化は極 めてわずかであり，また定数 $k_{1}$ は $k_{2}$ に比へて小 さく(一例では $k_{2}=6.9$ に対して $\left.k_{1}=0.9^{(7)}\right), k_{3}$ は 
k $k_{2}$ より更に大きいと予想されるので，本諭文では (4) 式を仮定し，運轱による経年劣化を受けたコイル群と 强制少化を与えたコイル群の実験結果を解析し，式の 要当性を考察する。

$$
V_{R}=100-k_{2}\left(\Delta-\Delta^{\prime}\right)-k_{3} \log \left(Q_{m} / Q_{m}{ }^{\prime}\right)
$$

\section{3. 実験}

〈3.1〉供試コイル 次の3 種のコイル群を供試 した。

(A): 連転歴 10 年の $10 \mathrm{MVA}, 6.6 \mathrm{kV}$ 水車発電 機のコイル 20 本。

$(B),\left(B^{\prime}\right)$ : 㞄転歷16年の $950 \mathrm{~kW}, 6.6 \mathrm{kV}$ 誘導電 動機のコイル50本。初め(B)群として30本供試 し，次に追加試料 (B') 群として 20 本供試した。

(C)：静的曲げひずみ負荷，課電，熱の強制劣化を 与えた $11 \mathrm{kV}$ 級モデルバーコイル10本。

ことで（A)扰よ゙(B)のコイル群はフレークマイカ ・不飽和ポリエステルレジン絶縁であり，(C)のコイ ル群はフレークマイカ・エポキシレジン絶縁である。

〈3.2〉 試験方法 各コイル群とも，主電極(低抵 抗塗料または導電性塗料を塗布）の両側にガード電極 を設け，これを接地し，端部の沿面放電を除いて非破 烄特性を測定した。測。定はまずシェーリングブリッ

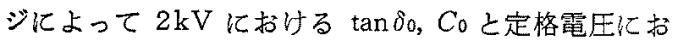
ける $\tan \delta_{E}, C_{E}$ を測定し， $\Delta$ を $\Delta=\Delta \tan \delta+\Delta C / C_{0}=$ $\left(\tan \delta_{E}-\tan \delta_{0}\right)+\left(C_{E}-C_{0}\right) / C_{0}$ に上って算出した。 次に常規電圧 (定格電圧 $\div V \overline{3}$ ) 在印加し， 1 サイク ルあたり 1 個以上安定してでる部分放電電荷の最大值 を，広带域法によって測定し $Q_{m}$ とした。(A)群と

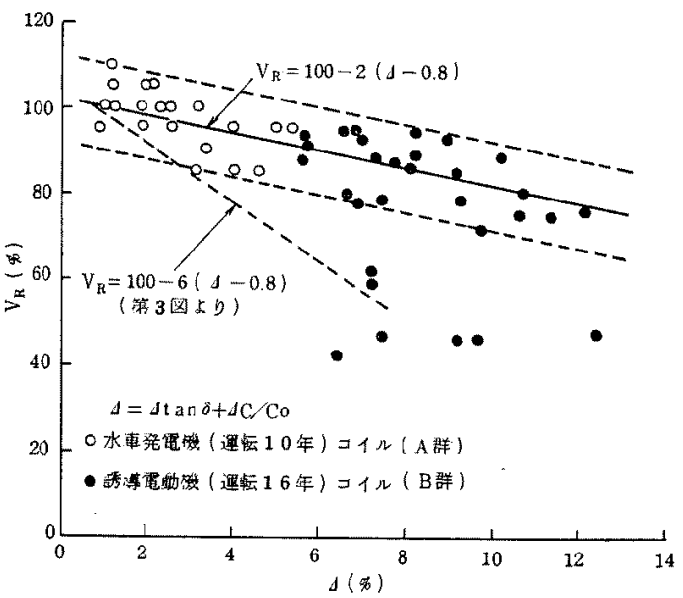

第 2 図 残存絶縁破壊電圧 $V_{R}$ 亡 $\Delta$ の相関

Fig. 2. Correlation between residual breakdown voltage $V_{R}$ and $\Delta(1)$.

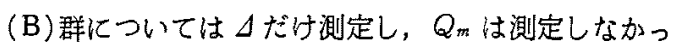
た。非破塄特性測定後に，全コイルにシリコンカーパ イド熋料の電界緩和廉を施し，室温の鈗油中に浸せき し，交流電圧を $1 \mathrm{kV} / \mathrm{s}$ の昇王速度で印加し，短時間 絶縁破壊試験を実施した。

実際の巻線を診断する場合には，ガード電極を設け ることは不可能であり、コイル端の沿面放電や隣接コ イル端間の放電が入るため，測定された $Q_{m}$ が絶縁層 内部のむのが見分けるのが難しい。また，電界楥和首 の影響が $\tan \hat{\delta}_{0}$ 扰よび $\Delta$ に入ってくる。しかし，乙 こではマイカ・レジン絶縁コイルの絶縁䛦断の可能性 を考察するのが目的であるから，ガード電極を設け て，絶縁層内部の問題传限定しておく。

〈3.3〉実験結果実験結果は次章の考察汇便利 なように，非破㙹测定值と残存絶縁破壊電圧 $V_{R}(\%$

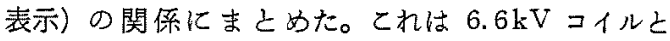

第 2 表 強制劣化コイルの特性

Table 2. Properties of compulsory degraded coils.

\begin{tabular}{|c|c|c|c|c|c|c|c|}
\hline \multirow{2}{*}{$\begin{array}{c}3 \\
1 \\
\mu \\
\text { 覾 }\end{array}$} & \multicolumn{3}{|c|}{ 強制多化条件 } & \multirow[b]{2}{*}{$\begin{array}{c}\Delta \text { at } E \\
(\%)\end{array}$} & \multirow{2}{*}{$\begin{array}{l}Q_{m} \text { at } \\
E / \sqrt{3} \\
\left(\times 10^{-9} \mathrm{C}\right)\end{array}$} & \multirow[b]{2}{*}{$\begin{array}{l}V_{R} \\
(\%)\end{array}$} & \multirow[b]{2}{*}{$\begin{array}{c}V_{R} \\
\text { 計悬雃 } \\
(\%) \\
(\%)\end{array}$} \\
\hline & 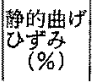 & 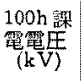 & 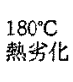 & & & & \\
\hline 1 & - & - & - & 0.8 & 1.5 & 100 & 100 \\
\hline 2 & 0.10 & 一 & - & 1.1 & 1.6 & 92 & 97 \\
\hline 3 & 0.20 & - & . & 3.1 & 2.5 & 80 & 82 \\
\hline 4 & - & 35 & - & 2.4 & 1.8 & 84 & 92 \\
\hline 5 & - & 30 & - & 1.8 & 2.0 & 89 & 91 \\
\hline 6 & 0.10 & 30 & - & 3.2 & 2.8 & 84 & 80 \\
\hline 7 & 0.10 & 25 & - & 2.9 & 2.5 & 86 & 83 \\
\hline 8 & 0.20 & 25 & $\longrightarrow$ & 7.0 & 3.0 & 66 & 68 \\
\hline 9 & $\longrightarrow$ & $\longrightarrow$ & 30 日 & 5.4 & 3.0 & 66 & 74 \\
\hline 10 & - & - & 30 日 & 5.9 & 3.2 & 61 & 66 \\
\hline
\end{tabular}

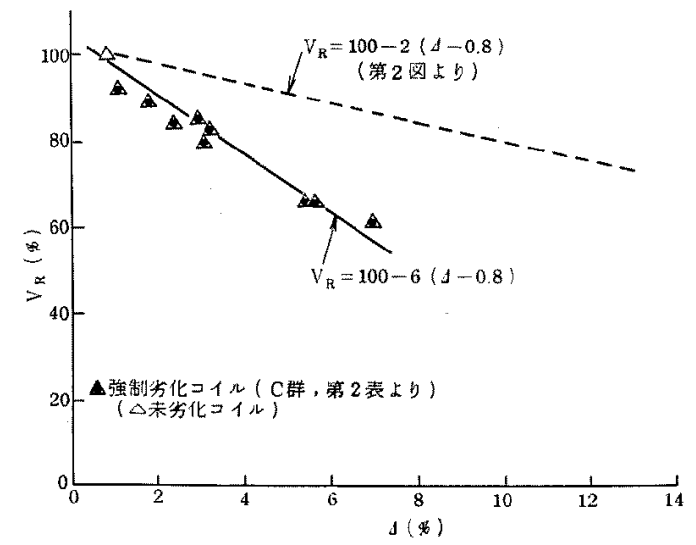

第 3 図 強制少化コイルの $V_{R}$ と $\Delta$ の相関 Fig. 3. Correlation between $V_{R}$ and $\Delta$ for compulsory degraded coils. 


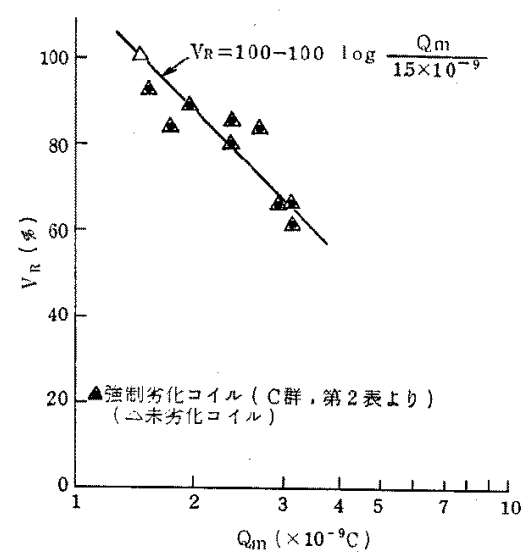

第 4 図 強制劣化コイルの $V_{R}$ と $Q_{m}$ の相関

Fig. 4. Correlation between $V_{R}$ and $Q_{m}$ for compulsory degraded coils.

$11 \mathrm{kV}$ 級コイルを統一して解析するためである。

第2四は (A)群のすべてと(B)群のうちの 30 本に ついて， $V_{R}$ 上 $\Delta$ の相関をまとめた。第 2 表は(C) 群の強制劣化条件亡 $A, Q_{m}, V_{R}$ をまとめた(7)。第 2 表を $V_{R}$ と $\Delta$ の相関で示したのが第3图であり， $V_{R}$ と $Q_{m}$ の相関でまとめたのが第 4 図である。群の残り の20本について測定した結果をまとめた。

\section{4. 考察}

$\langle 4 \cdot 1\rangle V_{R}$ と $A$ の関係 第2図求よび第3図で $V_{R}$ と $\Delta$ の関係をると次のてとが言无る。

（i）経年運転舫化を受けたコイル群の大部分は， $V_{R}$ と $\Delta$ の関係がほぼ次式に従うような劣化を受けて いる(第2 図で次式を示す実線の上下に示した破線は \pm 10 の範团で次式に従うコイル群の範囲を示す)。

$V_{R}=100-2(\Delta-0.8)$

ここで, பは％表示の值である。

（ii）強制少化を与えたコイル群仿，同じくほぼ次 式に従うような劣化を受けている。

$$
V_{R}=100-6(\Delta-0.8)
$$

（iii）経年運転劣化を受けたコイル群のうち，約 2 割は(5)式よりかなりはずれ，(6)式近くなる。と れらのコイル(つまり誘導電動機コイル 7 本) は， $V_{R}$ が異常に低いが，பはその他のコイルとほとんど差が \$。

(iv) 以上のこよから，単化測定值 $\Delta$ から $V_{R}$ を 推定することは困難であることがわかる。

$\langle 4 \cdot 2\rangle \boldsymbol{V}_{R} \boldsymbol{C} \boldsymbol{Q}_{m}$ の関係 第4 図加ら, 強制劣 化を与えたコイル群は $V_{R} と Q_{m}$ の間に相関がみら れ，ほぼ次式に従うことがわかる。

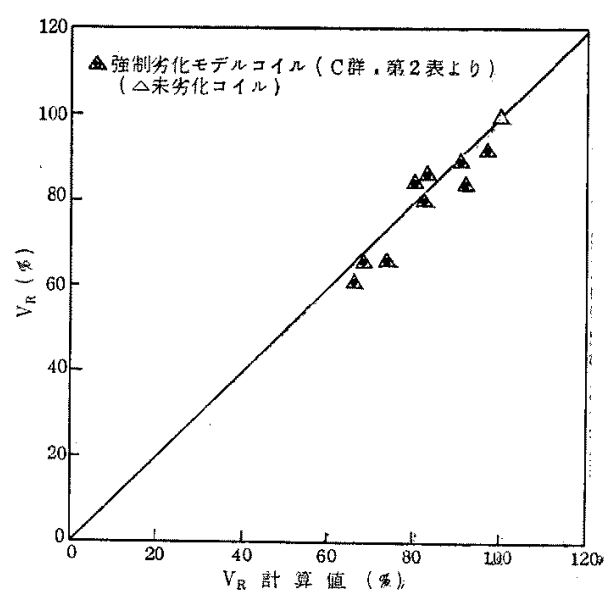

第 5 図 強制劣化コイルの $V_{R}$ (実測値) と $V_{R}$ 計算值の相関

Fig. 5. Correlation between $V_{R}$ (measured) and calculated $V_{R}$ for compulsory degraded coils.

$$
V_{R}=100-100 \log \left(Q_{m} / 1.5 \times 10^{-9}\right) \quad \ldots(7)
$$

こてで， $Q_{m}$ はクーロン (C) 表示の值である。

〈4・3〉強制劣化コイル群の関係式 まず強制劣

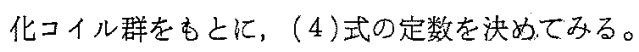

一般に経年運転劣化を受けたコイルの大部分につい ては(5)式が成立するので，むしてれらのほほ(5)式 に従うコイルの $Q_{n}$ が，劣化前の $Q_{m^{\prime}}\left(1.5 \times 10^{-9} \mathrm{C}\right.$ ) と注とんど变化しないのであれば，(4)式は次式のよ う汇表わせる。

$$
\begin{aligned}
V_{R}= & 100-2(\Delta-0.8) \\
& -k_{3} \log \left(Q_{m} / 1.5 \times 10^{-9}\right)
\end{aligned}
$$

ての（8)式方強制劣化コイルにもマッチするように 定数 $k_{3}$ を決的るそれれには强制劣化コイル群にマッ チする $V_{R}$ の式，(6)〜（8)式を連立方程式として 解く之 $k_{3}=67$ になる。そとで, 次式が強制少化コイ ル群にマッチする式として得られる。

$$
\begin{aligned}
V_{R}= & 100-2(\Delta-0.8) \\
& -67 \log \left(Q_{m} / 1.5 \times 10^{-9}\right) .
\end{aligned}
$$

第 5 図には強制㸓化コイル群 (第2 表) について, (9)式による $V_{R}$ 計算值と $V_{R}$ の実测值の関係をプロ ットしたが，両者はかなり良く一致する。

〈4・4〉 経年運転劣化コイル群の関係＼cjkstart経年運転 少化コイル群に対してあ(9)式が成り立つかどうかを みるため, 誘導電動機コイルを新たに 20 本供試し， とれを( $\left.\mathrm{B}^{\prime}\right)$ 群とした。第3表に( $\mathrm{B}^{\prime}$ )群のコイルの測: 定結果をまとめて示す。その測定做を(9)式代入し $V_{R}$ 計算值を求めた。その $V_{R}$ 計算値と $V_{R}$ の実測值 
第 3 表 16 年運転誘尊電動機コイルの特性

Table 3. Properties of induction motor coils used for 16 years.

\begin{tabular}{|c|c|c|c|c|c|c|c|c|c|}
\hline 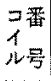 & $\underset{\text { at }}{\Delta}$ & $\begin{array}{l}Q_{\operatorname{mat}} \text { at } \\
E / \sqrt{3} \\
\left(\times 10^{-9} \mathrm{C}\right)\end{array}$ & $\begin{array}{l}V_{R} \\
(\%)\end{array}$ & $\begin{array}{c}V_{R} \\
\text { 壾簿値 } \\
(\%)\end{array}$ & $\begin{array}{l}a \text { 番 } \\
\text { 号号 }\end{array}$ & $\begin{array}{l}\Delta \\
\text { at } E \\
(\%)\end{array}$ & $\begin{array}{c}Q_{m} \text { at } \\
E / \sqrt{3} \\
\left(\times 10^{-0} \mathrm{C}\right)\end{array}$ & $\begin{array}{c}V_{R} \\
(\%)\end{array}$ & $\begin{array}{c}V_{R} \\
\text { 計算值 } \\
(\%)\end{array}$ \\
\hline I & 7.4 & 3.4 & 55 & 63 & 11 & 6.7 & 1.8 & 83 & 84 \\
\hline 2 & 7.1 & 1.5 & 86 & 87 & 12 & 7.6 & 2.4 & 73 & 74 \\
\hline 3 & 8.5 & 2.0 & 73 & 78 & 13 & 9.4 & 6.6 & 40 & 45 \\
\hline 4 & 10.2 & 2.0 & 70 & 73 & 14 & 12.6 & 5.0 & 43 & 41 \\
\hline 5 & 9.7 & 4.7 & 42 & 49 & 15 & 8.1 & 1.5 & 92 & 85 \\
\hline 6 & 12.2 & 1.9 & 71 & 71 & 16 & 9.8 & 2.7 & 67 & 65 \\
\hline 7 & 10.8 & 1.8 & 76 & 76 & 17 & 9.6 & 1.5 & 85 & 82 \\
\hline 8 & 7.1 & 3.4 & 58 & 66 & 18 & 7.8 & 1.8 & 82 & 82 \\
\hline 9 & 8.5 & 1.5 & 84 & 85 & 19 & 9.2 & 1.5 & 83 & 83 \\
\hline 10 & 8.9 & 1.5 & 89 & 84 & 20 & 6.6 & 1.5 & 90 & 82 \\
\hline
\end{tabular}

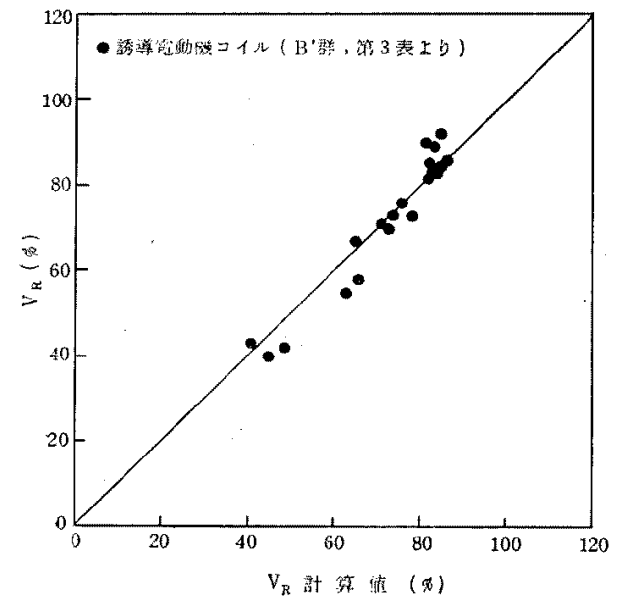

第 6 图 16 年運䎐誘尊電動機コイルの $V_{R}$ (実測侹)と $V_{R}$ 計算値の相関

Fig. 6. Correlation between $V_{R}$ (measured) and calculated $V_{R}$ for induction motor coils used for 16 years.

の関係をプロットしたのが第 6 図であるが，両者はか なり良く一致する。つまり，経年運転少化コイル群に 対してす(9)式がよくマッチする。

芯た、ジンが不飽和ポリエステルレジンであって むニポキシレジンであってむ，共通して(9)式があて はまることは，悉化形態加良く似ていることによると 考兑られる。アスファルト維縁上異なり、レジンの耐 熱性，耐機械力があるレベル上上糜れていて熱步化し に〈いものであれば，劣化はマイカとレジンの界面の 徽小ばくり加主として生ずると考えられ、レジンの 種類にはあまり関係ないのであるう。

〈4.5〉彷来の劣化判定基準上の関係 コンパウ ンド絶縁 $6.6 \mathrm{kV}$ 巻線の劣化判定基準山，牫存絶縁破 罱電圧方 $2 E+1 \mathrm{kV}$ (ここて， $E$ は定格電圧）以上あ るかどうかを判定するための基準であり， $\Delta \tan 8 \leq 6.5$

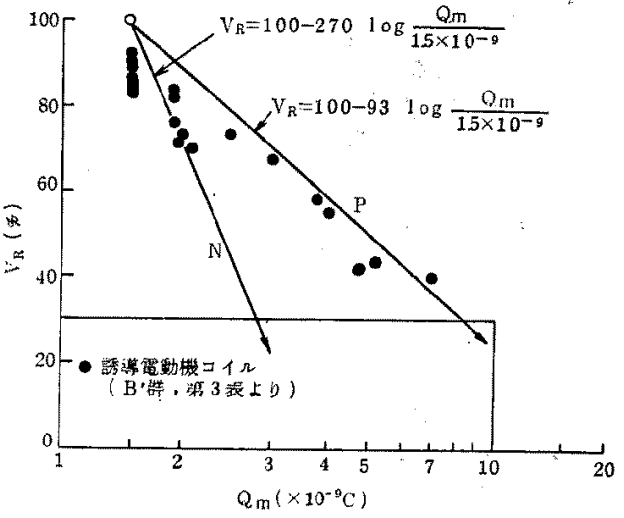

第 7 図 電動機コイルの $V_{R} \succeq Q_{m}$ の相関

Fig. 7. Correlation between $V_{R}$ and $Q_{m}$ for used induction motor coils.

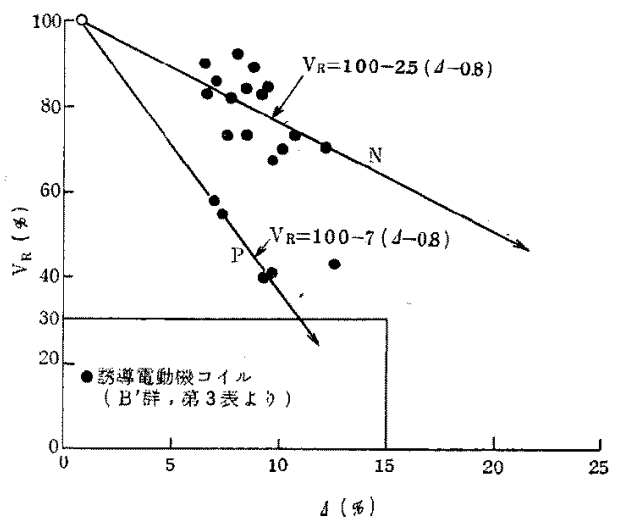

第 8 図 電動機コイルの $V_{R}$ と $\Delta$ の相関 Fig. 8. Correlation between $V_{R}$ and $\Delta$ for used induction motor coils.

$\%, \Delta I \leq 8.5 \% ， Q_{m}<10 \times 10^{-9} \mathrm{C}$ (それぞれ第 1 表参 照)の3項目中 2 項目がパスすればよいとさ扎てい る(1)。 $\Delta I \simeq \Delta C / C_{0}$ であるから，前の 2 項目を $\Delta$ 基 準になおすと， $\Delta \leq 15 \%$ に相当する。

第 3 表に記した（B)群コイル 20 本のデー夕を，上 記基準と比較するため，第 7 図放よび第 8 図のように $V_{R}$ と $Q_{n}$ および $A$ との関係でプロットした。 $V_{R}$ と $Q_{m}$ あるいは $\Delta$ 歹の関係表わす近似式は (5)，(6)， (8)式加ら幾分ず扎ている。

初期コイルの絶緣破填電王は，一般に定格電压の4 〜6 倍价るよう設計されている。そこで試験電圧は $V_{R}$ にして 50〜30\% に相当する。ここでは $V_{R}=30 \%$ のところを終点と仮定して，ラインを引いて比べて る。図中， $N$ は定常少化コイル群，Pは局所劣化を 含むコイル群けまり $\Delta$ の割に $V_{R}$ が異常に低いコ イル群) を表わす。乙れから次のととが言える。 
（i）従来の劣化判定基準は，局所劣化を含む $P$ 群コイルにはほぼマッチする。

（ii）定常劣化している $N$ 群コイルには， $Q_{m}$ の 基準は濖すぎ， $\Delta$ の基準は厳しすぎる。

（iii）ある年月以上運転した巻線には，必ず局所劣 化が生じていると考えるならば，巻線として全コイル 索測定すると $Q_{m}$ は最大值， $\Delta$ は平均値がでるの でほほ $P$ 群の線にのり，レジン巻線の劣化判定を 従来の基準で行なってもさほど問題はない。

〈4.6〉 D. MAP による表示法 第 9 図は，第 2 表と第 3 表のデータを， $\log Q_{m}$ を $X$ 軸， $\Delta を Y$ 軸 に目盛った座標にプロットした $\Delta$ と $Q_{m}$ の相関マッ プである。 $\Delta$ む $Q_{m}$ も放電に関連する值であるから， てれを Discharge Map (D. MAP と略記) と称する。

(9)式で表わされる関係を， $V_{R}$ をパラメータとし て描くよ直線で表加される。また， $6.6 \mathrm{kV}$ コンパウ ンド絶縁巻線の劣化判定ラインは破線のようになる。 プロットされたコイル群は， $N$ 群と $P$ 群に大別され る。それぞれ少化が進行するほど矢印の方向へ移行す ると考えられる。 $X$ 群は定常劣化コイルに局所劣化 が発生し，進展しつつ市るものと考えられる。

(9) 式に基づく $V_{R}=30 \%$ のラインと従来の劣化判 定ラインを比べると，局所劣化を含を $P$ 群コイルに 対しては活保一致するが，定常劣化の $N$ 群コイルに 対しては，従来の劣化判定ラインは跾しすぎると言え よう。

第 10 因は $\Delta C / C_{0}$ と $\Delta \tan \delta$ の相関をプロットし

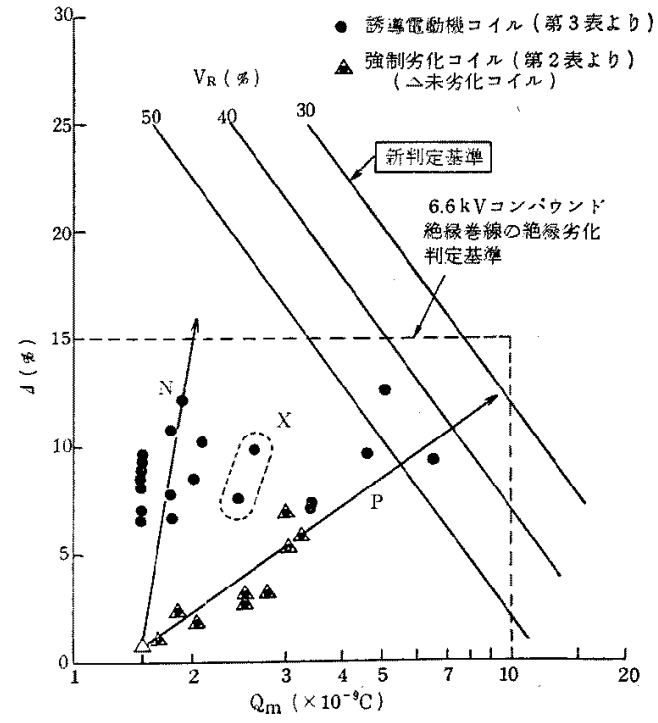

第 9 図 $\Delta 亡 Q_{\pi}$ の相関マップ

Fig. 9. Correlation map of $\Delta$ and $Q_{m}$.

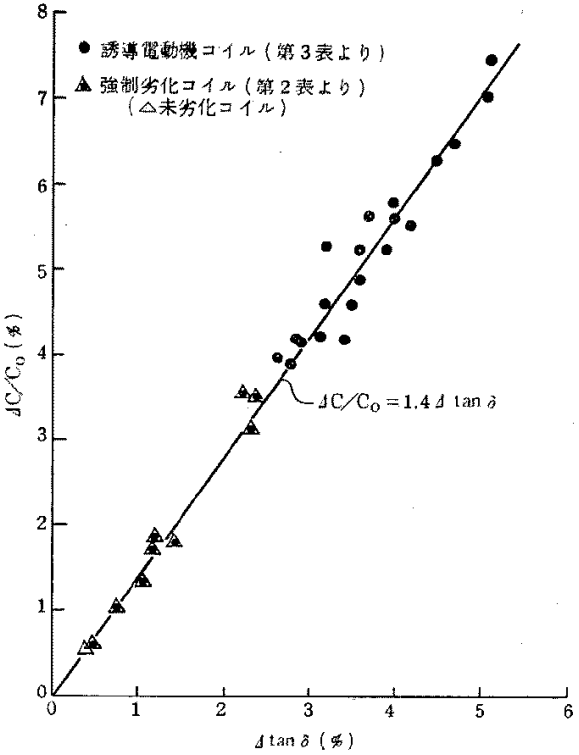

第 10 図 $\triangle C / C_{0}$ 之 $\triangle \tan \delta$ の相関

Fig. 10. Correlation between $\triangle C / C_{0}$ and $\triangle \tan \delta$.

たが、 $\Delta C / C_{0} \simeq 1.4 \Delta \tan \delta$ の関係が， $N$ 群コイル， $P$ 群コイルを問わずそ成り立つととがわかる。そこで， D. MAP D $Y$ 朝として， $\Delta C / C_{0}$ をとっても $\Delta \tan \delta$ をとってむよいと言える。あえてむをとったのは， 将来に㧍いて AIA に上る $\gamma$ 值を採用する場合のこと

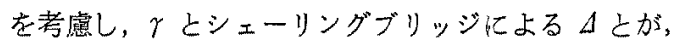
実験的に割と良く一致するととがわかったととによ る。

\section{$\langle 4 \cdot 7\rangle$ 運転中回転機巻線の絶縁診断上の問題点}

巻線の定期点検時に $\Delta$ と $Q_{m}$ を測定し，乙れを $\mathrm{D}$. MAPにプロットし，経年変化を追跡することによっ

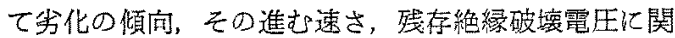
する有力な情報が得られるであるう。絶縁の更新が必 要となるライン（例え洁， $V_{R}=30 \%$ のライン） と共 亿，例えば $V_{R}=50 \sim 60 \%$ のラインをコイル抜取り 精密検査を要するラインとして記入してもよい。

実際の巻線に対して D. MAP 表示法を適用する場 合に問題となるのは，測定された $\Delta$ およひ $Q_{m}$ が絶 縁層のそれなのかどうかである。

まず，電界緩和層が電界非線形抵抗特性をむつシリ コンカーバイド染料の場合には， オに影響が入るので 適正な補正が必要上なる ${ }^{(8)}$ 。

また，巻線が吸湿ないし污損した場合には、、ンド 放電の $Q_{m}$ 吕絶緑層内部放電の $Q_{m}$ より一けた程度 大きくなることがある帛。 $Q_{m} \geq 1 \times 10^{-8} \mathrm{C}$ と測定され 
た場合にも，エンド放電に起因している可能性がある ので，例えば池田氏らが見いだした ${ }^{(9)}$ 最大放電電荷一 電圧特性の傾き $Q_{m}$ を加味して, 最終的な絶縁劣化判 定を行なう必要がでててよう。ての問題については, 将来に拈いて $\Delta$ (あるいは AIA による $\gamma$ で固き換 える) 抽び $Q_{m}$ の測定を自動化し，電圧による と $Q_{m}$ の変化を D. MAP 上の軌跡として表わす方法 によって，エンド放電かどうかを見分ける情報が得ら れると思っている。

また，最近の絶縁には，フレークマイカに代わって 集成マイカが普及しつつある。集成マイカ・エポキシ 絶縁の運転経年劣化コイルについて，本研究のような 実験を行なう機会はまだないが，強制劣化を与えたも デルバーコイルで実験したところ，かなり異なった劣 化形態を示すととがわかった。また，同じ集成マイカ・ エポキシ絶縁でむ，減压加压含浸方式かプリプレグ方 式か炕って暴なり，同じプリプレグ方式でも哀打材 (ガラスクロスか不織布)，集成マイカ(軟質加硬質 か，古るいは焼成か未焼成）およびレジンの㮔類に上 って異なる。とれは，フレークマイカではマイカ片内 のはがれという共通点があるのに，集成マイカではマ イカ小片 (普通, 平均直经 $0.4 \sim 1.0 \mathrm{~mm}$ ) 内の微小は くりが，いわゆる局所劣化へと進展するのに，レジン とマイカの接着強さやレジン自体の強さが大きく影響 するからであるう。

いずれにしろ集成マイカ・レジン絶縁の劣化判定基 準は、フレークマイカ・レジン絶縁のそれとは別に決 める必要功あり, かつ, 各メ一力の絶縁に対して少し ずつ異なっった基盏が必要亡なる可能性が強い。

更に巻線に発生した放電を，ライン側あるいは中性 点接地線側のいずれから測定するにせよ， $Q_{m}$ はかな り減衰してでてくることになる。その減衰の程度は放 電発生コイルの巻線申の位置によって異なるため, 減 較を考えなくてもよいコイル単体について定めた基準 を，そのまま巻線にあてはめることはできない。通常 は，運転中に加わる電圧が高いライン側に近いコイル の方が劣化が激しく，局所劣化す生じやすいと考え， ライン側で $Q_{m}$ を测定すればよいとされているが, (B) 群コイルの局所劣化コイルの位置は必ずしむライ
ン側に近くはなく，むしろ巻線中に散ばっていた。 今後しばらくの間は，フレークマイカ・レジン絶縁 の巻線について, 非貱罗試験书よび破壊試験のデー タ，あるいは抜取コイルと巻線のデータなどを $\mathrm{D}$. MAP で整理し，その有用性をチェックしたいと考え ている。

\section{5. よ め}

以上,フレークマイカ・レジン絶緑コイルの絶緑少 化診断について報告した。そこから得られる結論㹥次 のようになる。

（1）経年運転劣化コイル群および強制劣化コイル 群のなかには，一椂劣化コイル上局所的異常劣化コイ ルとが存在する。

（2）本研究で供試したいずれのコイル群にも共通 して，次の残存絶縁破壊電圧算出式が適用できた。

$$
\begin{aligned}
V_{R}= & 100-2(\Delta-0.8) \\
& -67 \log \left(Q_{m} / 1.5 \times 10^{-9}\right)
\end{aligned}
$$

(3) $\log Q_{m}$ を $X$ 軸， $\Delta を Y$ 軸に目盛ったてD. MAP」上にプロットすると，定常少化方向之局所少 化方向，すなわ劣化の形態が判別できる。

(4) $V_{R}=30 \%$ を一応の使用限界ラインとして， コンパウンド絶縁巻線の基準と比較すると, 局所劣化 を含む巻線に対してはほぼ一致する。

終わに，本研究に対し有益な討論をいただいた，日 立製作所日立工場 仕山部長, 松延副技師長, 安芸主任 技師，並びに日立研究所宮下主管研究員，および実験 に協力していただいた同所高村技師，藤岡君に感謝の 意を表する。

(昭和 54 年 11 月 19 日受付, 同 55 年 5 月 24 日再受付)

\section{文献}

（1）笔中研技卦，No.67001 (炤 42)

（2）池田, 他: 同上, No.175526 (昭 51)

(3) 東村, 他: 電気学会緦缘材料研資 EIM-78-74 (昭 53)

（4）平森，他: 電学猃 A，94，317 (昭 49-8)

(5) 寺瀨, 他 : 同上A，93，45(昭 48-2)

(6) 門谷, 他: 日立評譣, 61，355(昭 54-5)

(7) 門谷, 他: 電学諭 A, 100, 250 (昭 55-4)

（8）門谷, 他：昭54電気学会東家支大 63

（9）池田，他：笔中研技報，No.176023 (昭 51) 